IJJM

Ilomata International Journal of Management

P-ISSN: 2714-8971; E-ISSN: 2714-8963

Vol. 1 No. 2 March 2020 pp.38-44

https://www.ilomata.org/index.php/ijim

\title{
Effect of Total Members and Current Ratio on the Rest of Cooperative
} Business Result

\author{
Firdaus \\ Faculty of Economics \\ Kalimantan Islamic University Muhammad Arsyad Al Banjari Banjarmasin \\ Correspondent: ampuh53@gmail.com
}

Submitted: February $23^{\text {th }}, 2020 \quad$ Revised: March 15th $2020 \quad$ Published: March $30^{\text {th }}, 2020$

\begin{abstract}
This study aims to analyze the effect of a variable number of members and the current ratio on the remaining business results (SHU). The sample used is all data for the time series period 20122018. The data used are secondary, and the method used is multiple linear regression analysis with the help of the SPSS Version 23 program to obtain the influence of the independent variables with the dependent variable. The results showed that the number of members had a positive and significant effect on the residual consequences of operations; the current ratio had a negative and significant impact on the remaining results of operations.
\end{abstract}

Keywords: Number of Members, Current Ratio, SHU

\section{INTRODUCTION}

Nowadays, the impact of globalization is increasing rapidly, especially companies in processing economic resources to provide goods or services to the public at large. Further explained (Assauri, 2013), the financial resources consisted of 6M, namely, men, money, materials, methods, managerial skills, and markets. The management of economic resources done using effectiveness and efficiency. But many companies fail to manage because they are unable to keep up with market developments and dynamic business competition. Likewise, cooperatives as socio-economic organizations are required to be able to survive in the current conditions of change, both changes in terms of governance and human resources. The role of cooperatives strategic in the Indonesian economy, of course, must be realized in productive business activities both in production and marketing activities to support business sustainability, and it's time to leave the old ways and switch to using modern methods in business management.

The definition of cooperatives explained by (Rudianto, 2015), is "an association of people who voluntarily unite themselves to fight to improve their economic welfare through the establishment of a democratically managed business entity." Based on this explanation, the cooperative defined as the implementation of business activities, jointly managed by members, by members and for members strengthened by the existence of a collaborative legal entity following the applicable laws and regulations to prosper the members' economic well-being and have a family principle. Problems of cooperatives in Indonesia generally confronted with various issues related to 4 main aspects, such as aspects of an organization, business, human resources, and support systems, and business climate. In the case of elements organization, cooperatives with problems not correctly apply the principles of unions, besides unions not yet have a vision 


\section{Effect Of Total Members And Current Ratio On The Rest Of Cooperative Business Result Firdaus}

of modern competitiveness; furthermore, the issues of aspects of cooperative organizations are still low in professionalism and accountability in collaborative management.

Furthermore, collection problems related to business aspects members participationnamely, the lack of understanding of the involvement of members to advance and increase united capital - the lack of collaborative ability to meet the realization of production targets, into big goals. The problem aside from organizational and business aspects, cooperatives faced with human resource aspects, which are the many members' understanding of unions, the business orientation of cooperative human resources is still low, and the low capacity of human resources in accessing information technology. The problem of supporting system aspects and the business climate are also aspects that need attention, namely regulations and policies, both central and local governments.

This research conducted at the Siti Khadijah Cooperative Islamic Hospital in Banjarmasin. Business activities consist of savings and loans, shop business, and cleaning services. Based on Figure 1. the remaining business results of the Siti Khadijah Cooperative Banjarmasin Islamic Hospital 2012-2018 fluctuate. As was the case in 2013 decreased the distribution of the residual effects of operations. Many factors can affect the rest of the business results, including the number of members. Based on Figure 2., the number of members of the Cooperative Siti Khadijah Islamic Hospital Banjarmasin from 2012-2018, tends to increase members. The increase in members explained, namely, 2012 cooperative members totaling 186 people, in 2013 there were 210 people, in 2014 there were 236 people, in 2015 there were 242 people, in 2016 there were 249 people, in 2017 there were 252 people, and in 2018 there were 255 people.

Generally, increasing in the number of members accompanied by the rise in the residual results of operations, when the number of members increases and the member actively carries out savings and loans, the cooperative experiences an increase in profits. The increase in benefits should be in line with the rise in the distribution of the remaining results of operations. But the phenomenon that occurs is not the case. The dissemination of the remaining effects of activities experienced fluctuations from 2012-2018. The growth of a large number of members will certainly be able to encourage a sizeable residual business result, provided that the members are active.

Conversely, an increase in the number of members can also reduce the residual business results obtained when the members are passive or less active. The lack of active members of the cooperative caused by a lack of member participation in information in the collective, so the mass is still tough to develop (Ayuk, 2013). Many empirical studies prove that the number of members has a positive and significant effect on the remaining business results, such as the results of empirical studies (Ayuk, 2013); (Malinda, 2014); (Meitriana, 2015); (Winarko, 2014). The results of different empirical studies conducted by (Sudaryanti, 2017) the number of members does not significantly influence the rest of the business results. The existing research gap mentioned above is exciting to do a re-study related to the effect of the number of members on the remaining business results.

In addition to the number of members, the current ratio can also affect the residual results of operations. Based on Figure 3., the current rate from 2012 to 2018, has a ratio value of more than 2 to 1 . The means of the number of existing assets owned by the Siti Khadijah Cooperative Banjarmasin Islamic Hospital is quite large by the standard. The best current ratio 


\section{Effect Of Total Members And Current Ratio On The Rest Of Cooperative Business Result}

Firdaus

has a magnitude of around $200 \%$ or $2: 1$; this means that the cooperative can meet its short-term obligations.

Current asset value compared to current debt exceeds 2 to 1, then Siti Khadijah Cooperative of Banjarmasin Islamic Hospital can still increase its business activities by increasing business activities. If business activities raised, of course, it would increase cooperative income. Increased aggregate income allows the remaining business results will also increase. Many empirical studies have been carried out, such as (Albana \& Kusumantoro, 2015); (Albana \& Kusumantoro, 2015); (Hadi, 2013), which states that the current ratio does not significantly influence the residual operating results.

Based on the above background, the problem as formulated whether the number of members has a positive and significant effect on the remaining results of operations, whether the current ratio has a negative and significant impact on the remaining results of operations. Furthermore, based on the above problem formulation, the purpose of the study is to find out the number of members having a positive and significant effect on the remainder of business results; to find out the current ratio has a negative and significant impact on the remaining business results.

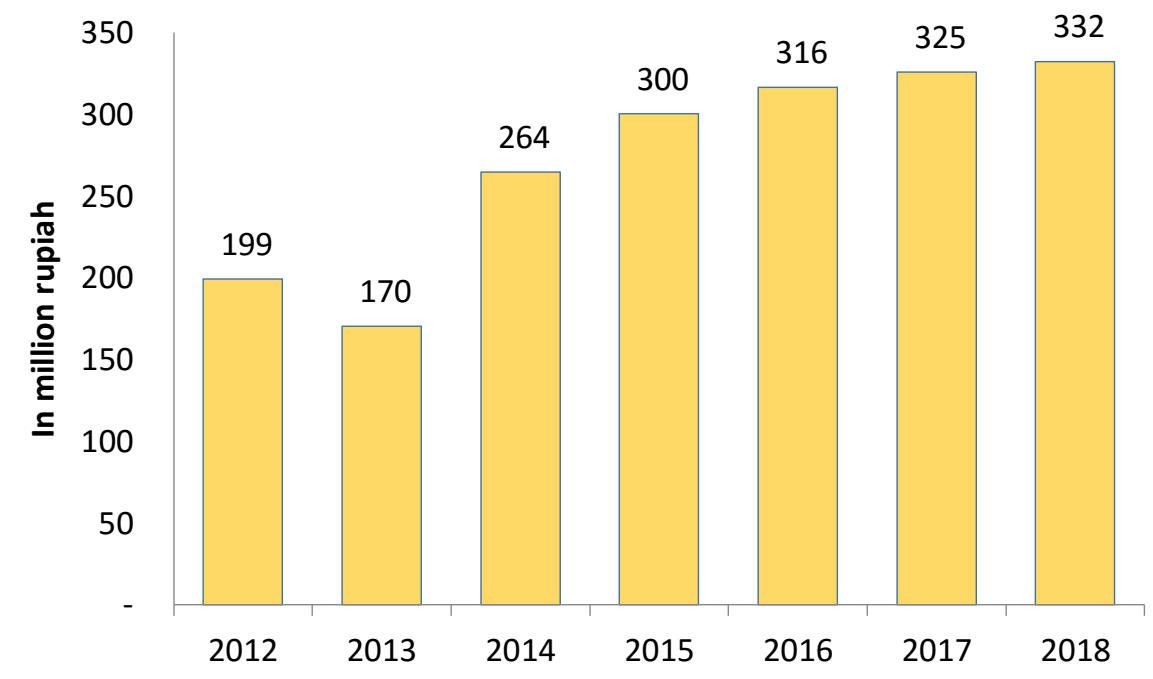

Source: Secondary Data Processed, 2020

Figure 1. Chart of Remaining Operating Results for 2012 to 2018

Cooperative Siti Khadijah Islamic Hospital Banjarmasin 
Effect Of Total Members And Current Ratio On The Rest Of Cooperative Business Result Firdaus

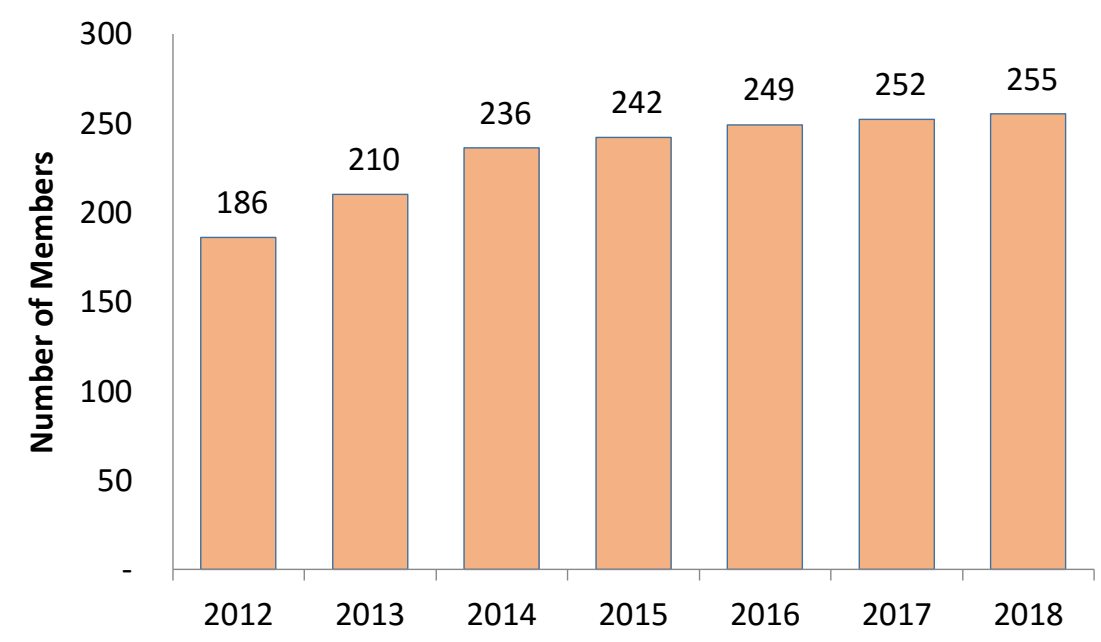

Source: Secondary Data Processed, 2020

Figure 2. Number of Members from 2012 to 2018

Cooperative Siti Khadijah Banjarmasin Islamic Hospital

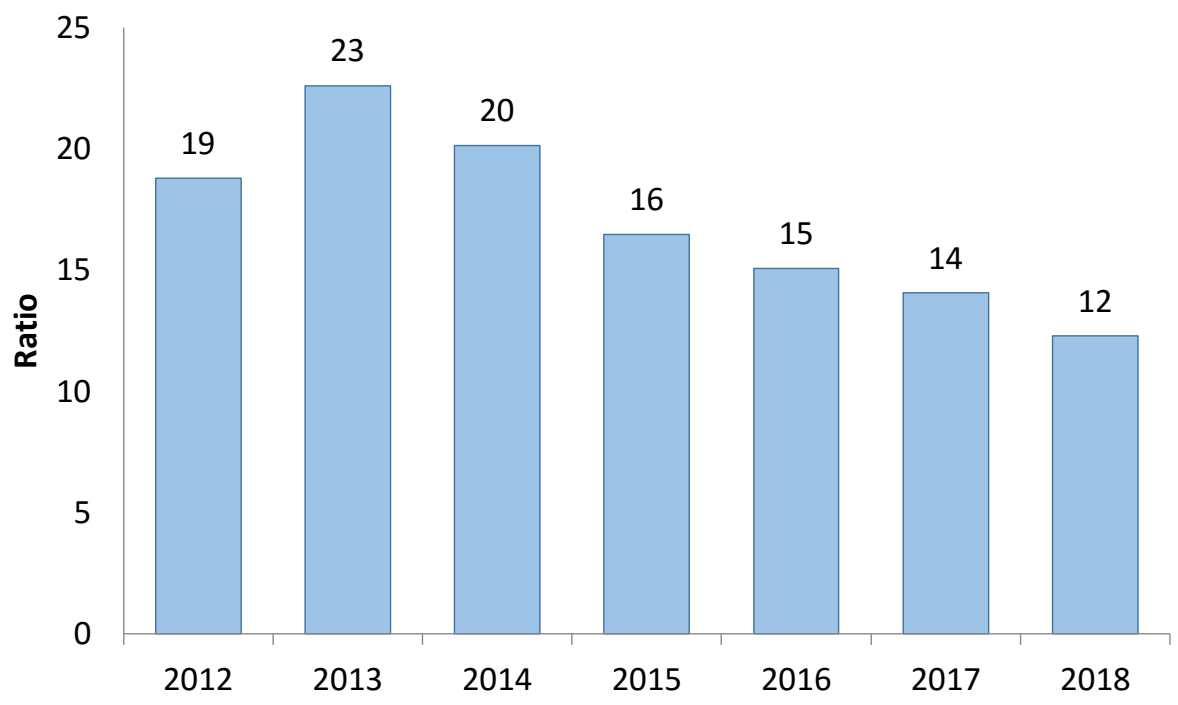

Source: Secondary Data Processed, 2020

Figure 3. Current Ratio from 2012 to 2018

Cooperative Siti Khadijah Islamic Hospital of Banjarmasin

\section{METHOD}

The research method used in this study is a descriptive analysis method with a quantitative approach that is by looking for information about the symptoms that exist, with clear objectives to be achieved, planning how to approach it, collecting data as material to make a report. The use of this quantitative descriptive method is associated with research variables that focus on actual problems and phenomena that occur today with the form of research results in the way of numbers that have meaning. The research variables divided into two main variables, 


\section{Effect Of Total Members And Current Ratio On The Rest Of Cooperative Business Result}

\section{Firdaus}

namely the independent variable $(\mathrm{X})$ consisting of the number of members (X1) and the current ratio (X2). In contrast, the dependent variable $(\mathrm{Y})$ is the residual income. Data analysis in this study uses multiple linear regression analysis methods. In this study using SPSS Version 23. The framework for this research is as follows:

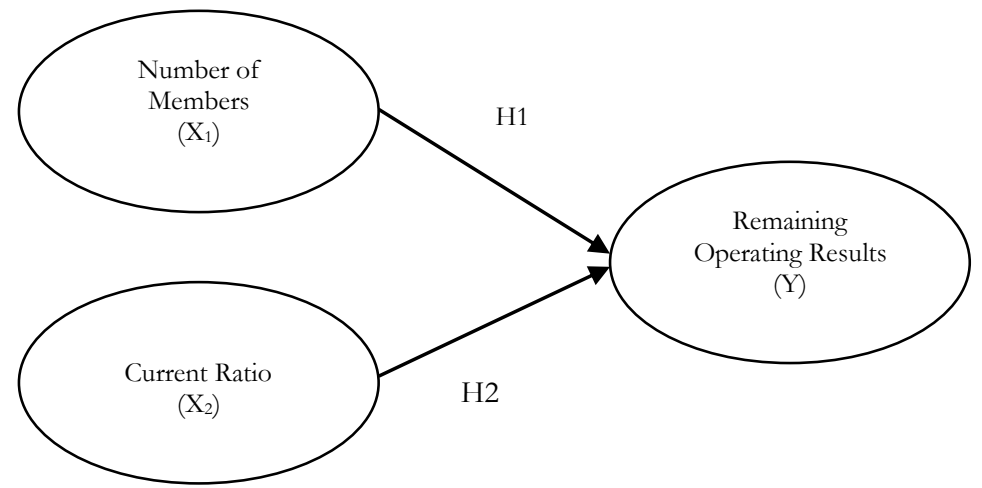

Figure 4. Conceptual Framework

\section{RESULT AND DISCUSSION}

Table 1. Results of Regression Analysis Using SPSS Version 23

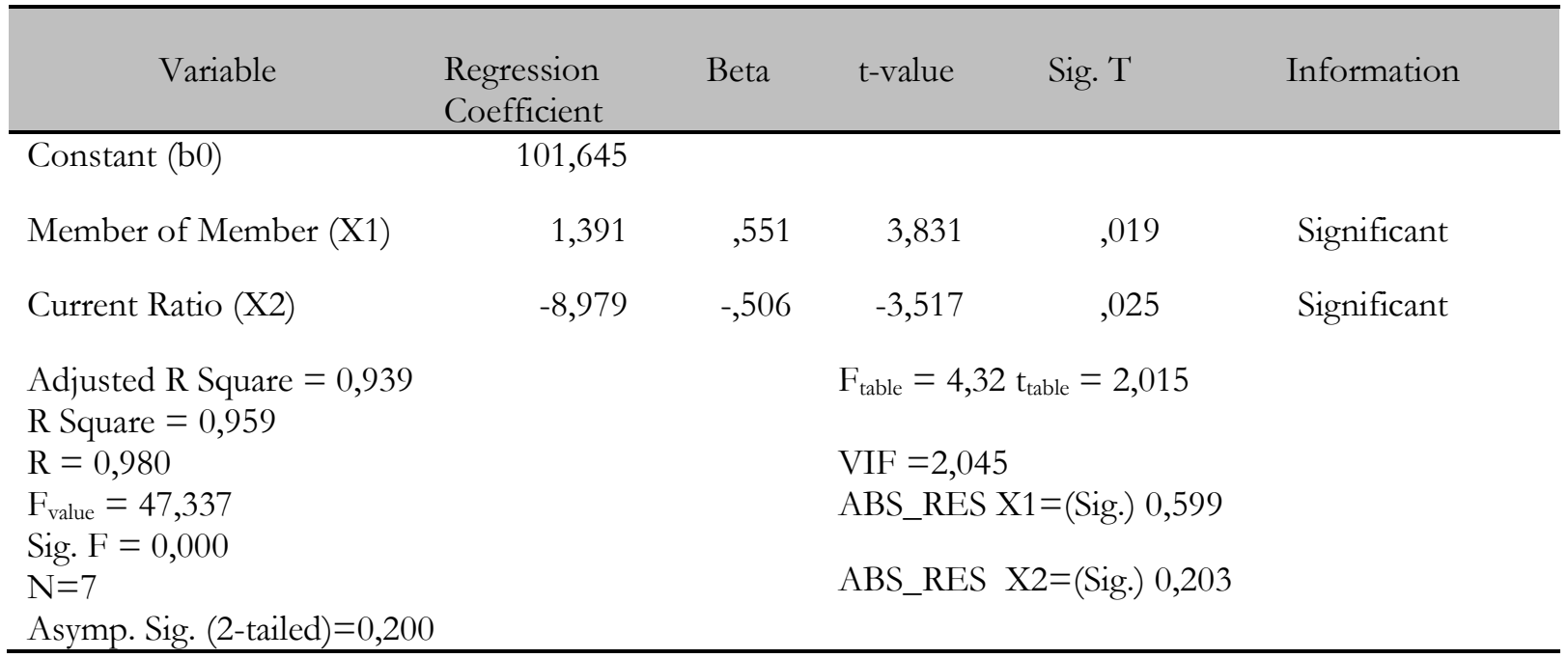

Source: Data processed, 2020

The test results above obtained a regression coefficient of 1.391 with a probability of 0.019 does not exceed the significance of 0.05 , which means the number of members has a positive and significant effect on the remaining business results. A positive regression coefficient of 1.391 explains that each increase in the number of members by $1 \%$ will decrease the names of members by 1.391, assuming the other ratios fixed. The higher the number of members, the stronger the cooperative's ability to share the remainder of its business results. The results of this study are in line with research conducted by (Ayuk, 2013); (Malinda, 2014); (Meitriana, 2015); (Winarko, 2014) whose results indicate that the number of members has a positive effect on the remaining business results. The higher the number of members, the stronger the cooperative's ability to share the remainder of the business results. Following the theory (Winarko, 2014), the growth of the number of cooperative members has a positive and significant role in the remaining business results. 


\section{Effect Of Total Members And Current Ratio On The Rest Of Cooperative Business Result}

Firdaus

Current ratio regression coefficient of -8.979 with a probability of $0.025<0.05$, which means a negative and significant effect on the remaining business results. The high current ratio shows that the availability of existing assets to meet current liabilities is also high. In contrast, existing assets contain accounts such as cash and cash equivalents, accounts receivable, inventories, and securities. However, the high current ratio does not guarantee that the cooperative has enough money to meet current obligations. The results of this study are consistent with research conducted by (Albana \& Kusumantoro, 2015); (Albana \& Kusumantoro, 2015); (Hadi, 2013) whose results show that the current ratio has no significant effect on the remaining business results.

\section{CONCLUSION}

Based on the results of research that has done, the number of members has a positive and significant effect on the remaining business results. Expected that cooperative management must maximize the number of members they have to become active members of the cooperative, thereby benefiting, so that the rest of the business results continue to increase. Related to the current ratio has a negative and significant effect on the remaining results of operations, expected that cooperative management manages funds effectively and efficiently how to channel funds to productive assets to get maximum profit so that the remaining operating results increase.

For other researchers, I hoped that the results of this study be used as a reference to study similar variables that have been discussed by the authors. For the number of observations to be added, other variables that have not been considered such as member satisfaction

\section{REFERENCE}

Aisyah, W. U. N., Salim, F., \& Sofyan, M. (2019). The Influence of Service Quality and Price on the Interest of Commuterline KRL Passengers. Ilomata International Journal of Management, 1(1), 13-18.

Albana, I. F., \& Kusumantoro. (2015). Pengaruh Modal Sendiri Dan Current Ratio Terhadap Sisa Hasil Usaha (SHU) Di KPRI Kota Semarang 2013. Economic Education Analysis Journal VO - $\quad 4, \quad 3 . \quad 4$ http://eresources.perpusnas.go.id:2048/login?url=http://search.ebscohost.com/login.aspx?direct= true $\& \mathrm{db}=$ edsdoj\&AN=edsdoj.f41bc10b231d49478a87b7f18263aff1\&site=eds-live

Ayuk, made taman. (2013). Pengaruh Jumlah Anggota, Jumlah Simpanan, Jumlah Pinjaman dan Jumlah Modal Kerja terbadap Sisa Hasil Usaba (SHU) Koperasi Simpan Pinjam (KSP) di Kabupaten Badung Provinsi Bali. http://eresources.perpusnas.go.id:2048/login?url=http://search.ebscohost.com/login.aspx?direct= true $\& \mathrm{db}=$ edsair\&AN=edsair.od......3622..decdb5e8d5573a271f4cd5e2b99e45c4\&site $=$ edslive

Assauri, Sofjan. 2013. Manajemen Pemasaran. Jakarta: PT Raja Grafindo Persada.

Arifin Sitio dan Tamba Halomoan. 2001. Koperasi : Teori dan Praktik. Jakarta : Erlangga.

Febrianty, \& Divianto. (2020). Business Owner'S Perspective on Strategic Execution, Technological Transformation, Competitiveness Potential, and Services Level on the Implementation of Strategic It Alignment. Humanities \& Social Sciences Reviews, 8(1), 567-585. https://doi.org/10.18510/hssr.2020.8169_1

Febrianty, F., \& Febriantoko, J. (2018). Pengaruh Intellectual Capital Terhadap Profitabilitas Perusahaan Sektor Makanan dan Minuman di Indonesia. Assets: Jurnal Akuntansi Dan Pendidikan, 7(1), 45-56. 


\section{Effect Of Total Members And Current Ratio On The Rest Of Cooperative Business Result}

\section{Firdaus}

Malinda, yola. (2014). Pengaruh Jumlah Anggota Dansimpanan Anggota Terhadap Peningkatan Sisa Hasil Usaha (SHU) Pada PKP-RI (Pusat Koperasi Pegawai Republik Indonesia) Propinsi Sumatera Barat. Economica 116. https://doi.org/10.22202/economica.2014.v2.i2.224

Meitriana, S. P. M. A. (2015). Pengaruh Jumlah Anggota Terhadap Perolehan Sisa Hasil Usaha Melalui Partisipasi Anggota Sebagai Variabel Intervening Pada Koperasi Simpan Pinjam Wisuda Guna Raharja Denpasar Tabun 2012-2014. Ganesha University of Education 2015. http://eresources.perpusnas.go.id:2048/login?url=http://search.ebscohost.com/login.aspx?direct= true\&db=edsoai\&AN=edsoai.ocn $999341257 \&$ site $=$ eds-live

Pariyasa, K. B., Zukhir, A., \& Indrayani, L. (2014). Pengaruh Modal, Volume Dan Anggota terhadap Sisa Hasil Usaha pada Koperasi Serba Usaha Kecamatan Buleleng. Jurnal Pendidikan Ekonomi JUPE), 04(01), 1-10. https://ejournal.undiksha.ac.id/index.php/JJPE/article/view/1896

Raidayani, R., Muhammad, S., \& Faisal, F. (2017). Faktor-Faktor yang Mempengaruhi Sisa Hasil Usaha (SHU) pada Koperasi di Kabupaten Aceh Barat. Jurnal Perspektif Ekonomi Darussalam, 3(2), 101-116

Rudianto. 2015. Akuntansi Koperasi. Jakarta: Erlangga.

Rulandari, N., Rusli, B., Mirna, R., Nurmantu, S., \& Setiawan, M. I. (2018). Valuation of production sharing contract cost recovery vs gross split in earth oil and gas cooperation contracts in Indonesia and the aspect of public service. Journal of Physics: Conference Series, 1114(1), 12132.

Sudaryanti, D. S. (2017). Pengaruh Jumlah Anggota, Modal Luar, Dan Total Asset Terhadap Sisa Hasil Usaha (Studi Empiris pada Koperasi Simpan Pinjam di Kota Tasikmalaya tahun 2016). In Ekspektra: Jurnal Bisnis dan Manajemen. Universitas Dr. Soetomo. https://doi.org/10.25139/ekt.v0i0.339

Supatmin, S. (2018). ANALISIS PENGARUH LIKUIDITAS, SOLVABILITAS DAN RENTABILITAS TERHADAP SISA HASIL USAHA PADA KOPERASI SIMPAN PINJAM "PDW" GROUP. In DISRUPSI BINIS. DISRUPSI BINIS. http://eresources.perpusnas.go.id:2048/login?url=http://search.ebscohost.com/login.aspx?direct= true $\& \mathrm{db}=$ edsair\&AN $=$ edsair.univpamulang..321ed64274e2c49a72c6cdda68597264\&site $=\mathrm{e}$ ds-live

Supriyanto. (2015). Tata kelola koperasi kredit atau koperasi simpan pinjam, Yogyakarta: CV Andi Offset.

Winarko, S. P. (2014). Pengaruh Modal Sendiri, Jumlah Anggota Dan Aset Terhadap Sisa Hasil Usaha pada Koperasi di Kota Kediri. Nusantara of Research, 01(2), 151-167. 